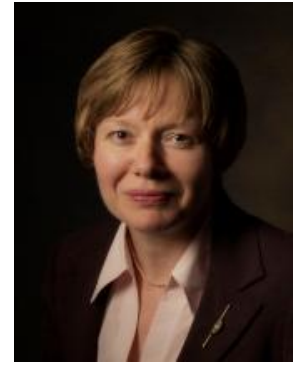

\title{
HOW SHOULD JOURNAL EDITORS RESPOND TO CASES OF SUSPECTED MISCONDUCT?
}

\author{
Elizabeth Wager
}

Publications Consultant, Sideview, UK; Visiting Professor, University of Split School of Medicine, Croatia

Corresponding Author: Prof. Elizabeth Wager, 19 Station Road, Princes Risborough, HP27 9DE, UK. Tel. (+44) (0) 1844275814,E-mail: liz@ sideview.demon.co.uk

NOTE: This article is also published in the Journal of Microbiology \& Biology Education (Vol. 15, number 2, theme issue on scientific ethics) December 2014.

\begin{abstract}
Journals and institutions have important complementary roles to play in cases of suspected research and publication misconduct. Journals should take responsibility for everything they publish and should alert institutions to cases of possible serious misconduct but should not attempt to investigate such cases. Institutions should take responsibility for their researchers and for investigating cases of possible misconduct and for ensuring journals are informed if they have published unreliable or misleading articles so that these can be retracted or corrected. Journals and institutions should have policies in place for handling such cases and these policies should respect their different roles.
\end{abstract}

Key words: Publication ethics, research misconduct, scientific journals, paper retraction

Introduction: why journals and institutions need to work together on cases of suspected misconduct?

Journal editors are often the first people to become aware of possible misconduct and therefore have a responsibility to respond appropriately. Journals also have a responsibility for everything they publish and should take appropriate remedial action if they discover they have published anything misleading or fraudulent. However, editors should not attempt to undertake formal investigations into research misconduct since they have neither the expertise, nor the legal standing, nor the resource to do so. Investigating misconduct should be the responsibility of the institution where the individual researcher was working at the time the alleged offences occurred. Therefore, it is important for journals and institutions to cooperate and exchange information over cases of possible misconduct. Until recently, little guidance was available on this topic, but in 2012, the Committee on Publication Ethics (COPE) published guidelines [1] to complement their other guidance for editors such as the COPE flowcharts [2]. This article is based on various COPE guidelines and on my experience as Chair of COPE (from 2009 \pm 2012 ) and attendance at COPE Forum meetings (since 2006) at which editors and publishers discuss troublesome cases.

The COPE flowcharts suggest actions editors should take to handle a variety of specific types of misconduct such as plagiarism or redundant publication. However, some cases do not fit neatly into any particular category or include several types of misconduct. I propose some generic guidelines applicable in all situations (Box 1). 


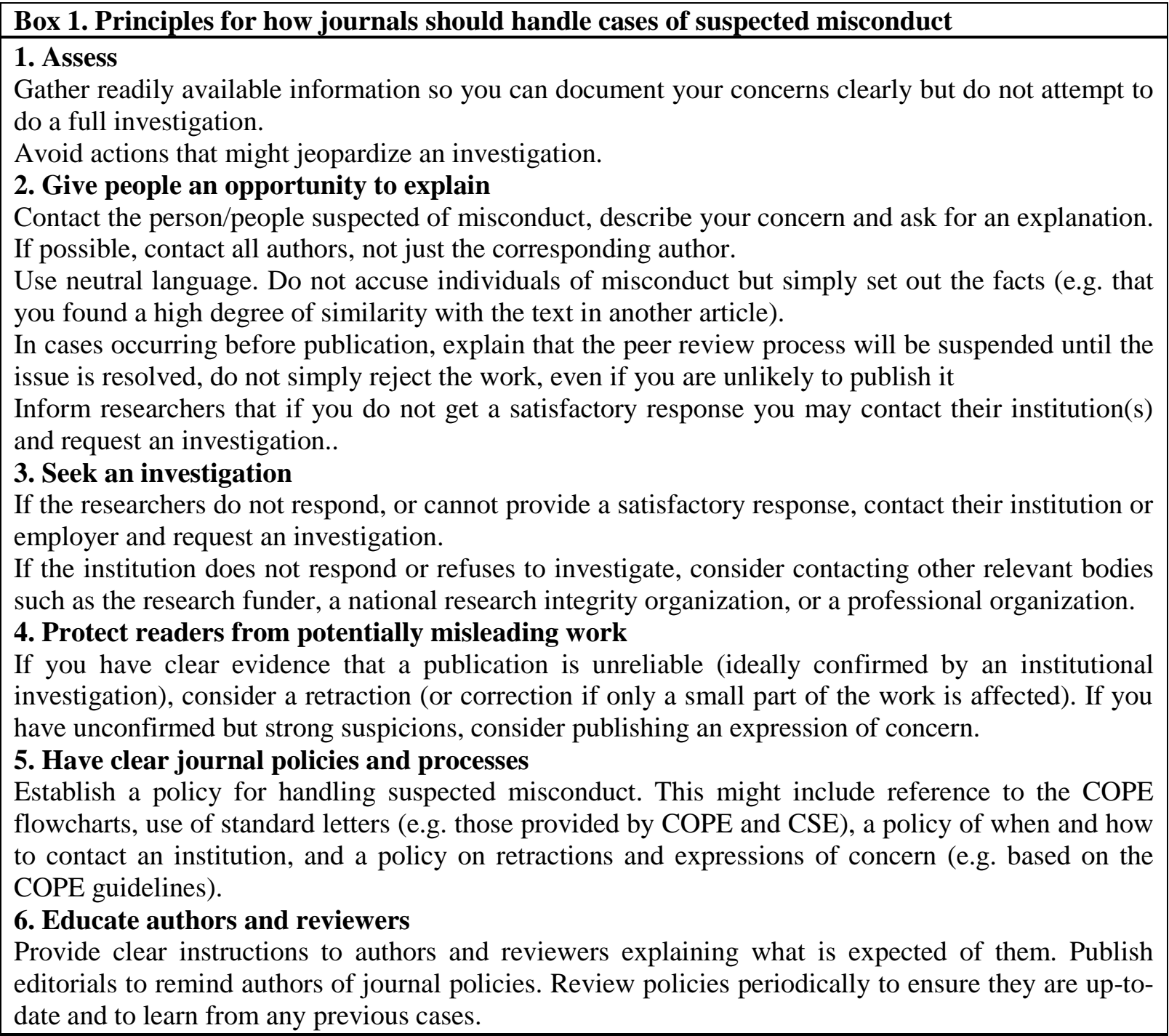

How do journal editors become aware of possible misconduct?

Journals may receive evidence of possible misconduct from a number of sources including peer reviewers, readers, and whistleblowers. Increasingly, journals also screen submissions for some forms of misconduct (most commonly plagiarism, redundant publication, and image manipulation) and must therefore react when problems are detected by these processes. Whatever the source, any evidence of possible misconduct should be taken seriously. However, allegations must be well grounded and journals may choose not to respond to vague allegations, or may require more concrete evidence to back them up before taking further action.

\section{How much investigation should journals do?}

Journals are not equipped to perform a full investigation, and this role must be left to the author's (or reviewer's) institution or employer. However, editors need to gather enough information to determine whether the case should be pursued, and to describe concerns to those suspected of misconduct and, if the researchers cannot provide a reasonable explanation, to their institution.

In some cases, editors may seek advice from experts to obtain further opinions and information (e.g. they may request additional peer review on a submitted or published article). In such cases, if suspicions of misconduct are shared, every effort should be made to ensure that this process is confidential (i.e. the name of the person suspected of misconduct is not revealed to the expert(s) and the need for confidentiality is stressed). In the case of allegations about published work, it is usually impossible to mask the identity of the author, so editors should take especial care when passing any information outside the journal and should remember that 
sharing allegations about identifiable individuals could constitute defamation.

Tools such as text-matching software or techniques to identify image manipulation may be helpful to quantify a concern or check the validity of an accusation.

\section{When should people suspected of misconduct be contacted?}

When the journal has well-founded suspicions and has documented the circumstances and details of the case, these should be passed to the individual(s) suspected of misconduct. When a case arises before publication it is best to suspend the peer review process rather than reject the submission, even if the journal intends to reject the work later. Authors are more likely to respond before rather than after their work has been rejected, since, once it has been rejected there is a risk they will ignore communications from the first journal and simply submit the work to another journal, perhaps after removing the evidence of misconduct.

\section{How should people suspected of misconduct be contacted?}

The journal's concerns should be stated in neutral terms avoiding any accusation of misconduct. For example, rather than using the word plagiarism, editors should ask authors to explain the large amounts of matching text found in another document. The Council of Science Editors (in collaboration with COPE) provides template wording for various situations which may be helpful [3].

The communication (usually by email) should explain the procedure the journal intends to follow, e.g. stating that peer review has been suspended and describing what the journal will do if a satisfactory response is not forthcoming. Ideally, all authors (not just the corresponding author) should be contacted. Author contact details may be available from bibliographic databases or institutional websites if they are not in the journal database.

The identity of informants or whistleblowers must be protected.

When should institutions be contacted?

In virtually all cases, the individual authors or reviewers should be given a chance to respond to the journal's concerns and the institu- tion is only contacted if the explanation is unsatisfactory, the researcher(s) admit misconduct, or there is no response. However, in very serious cases, or if the editor believes that contacting the individual researcher might cause them to destroy evidence that might be needed for an investigation, it may be advisable to contact the institution at the same time as, or even before, alerting the researcher(s).

Editors may be concerned that contacting an institution could lead to an unfair or disproportionate investigation. They may be especially concerned about contacting institutions if they have no knowledge of how cases of suspected misconduct might be handled. It is hard to know the extent to which such concerns are justified or how editors should balance their worries about how an individual will be treated with the journal's responsibility to pass on information about cases of possible misconduct so that the institution can investigate them. Not only is the institution the appropriate organization to investigate the behaviour of its researchers, but if journals share information about suspected misconduct, such information may provide evidence for an on-going investigation into other problems, highlight training needs, or inform institutional policies.

\section{How should institutions be contacted?}

The first task is to identify the right person to contact. The ease of doing this varies greatly between countries. If a university has a designated research integrity officer (as they usually do in the USA) this makes the editor's life much easier. If somebody with responsebility for research integrity cannot be identified from the website, a senior person such as a Dean or Pro-Vice Chancellor should be contacted. The journals' concerns should be set out objectively and concisely. It may be helpful to explain what further information the journal would be willing to release to the institution and what it is not prepared to share (e.g. to protect the identity of whistleblowers or peer reviewers).

Sadly, institutions do not always respond to journals' requests for an investigation, or may be unwilling to share information with journals [4]. Persistence is sometimes required, first to find the correct person to contact, and then to get a response. Recorded delivery letters 
may be more effective than emails in eliciting a response. If there is no response from the institution despite repeated communications, the editor should try contacting other organizations such as the research funder, professional bodies (e.g. medical licensing organizations in the case of doctors), or a national research integrity organization. Unfortunately, most countries do not have a national research integrity organization, and even when they exist, their remit may be limited (e.g. the Office for Research Integrity in the USA considers only cases of fabrication, falsification, or plagiarism in federally funded health research - it will not consider other issues, such as authorship disputes, or commercially funded research).

\section{The need for journal policies}

Journal responses to suspected misconduct should be fair and consistent. It is therefore helpful to have a written policy for how such cases are handled. Many journals refer to the COPE flowcharts which suggest a step-bystep approach for many types of case [2]. Because cases of serious misconduct are rare, most editors will not have experience of handling them, therefore journal publishers often play an important role and should be involved in developing policies. Many larger publishers provide resources to editors such as guidelines, websites, and helpdesks [5-8].

The COPE Code of Conduct for journal editors states that "Editors have a duty to act if they suspect misconduct or if an allegation of misconduct is brought to them. This duty extends to both published and unpublished papers. Editors should not simply reject papers that raise concerns about possible misconduct. They are ethically obliged to pursue alleged cases... Editors should make all reasonable efforts to ensure that a proper investigation into alleged misconduct is conducted; if this does not happen, editors should make all reasonable attempts to persist in obtaining a resolution to the problem. This is an onerous but important duty". [9]. Individual journal or publisher policies should provide detailed guidance such as when to contact an institution.

\section{Journal responses to misconduct affecting published material}

As well as having systems for handling cases of suspected misconduct, journals require policies and processes for retracting or correcting false information that they have published. Many journals refer to the COPE guidelines on retractions, which also cover corrections and expressions of concern [10]. Because retractions may be used both in cases of honest (unintentional) error and of fraud, COPE recommends that retraction statements should include the reason for the retraction. This may require liaison with the institution if an investigation has taken place. Authors may object to retraction notices that mention misconduct and may argue for more vague wording or even threaten legal action against the journal. Editors should take legal advice to avoid defamatory wording but should nevertheless strive to provide an informative statement. If the institution has issued a public statement following an investigation this makes the journal editor's task much easier, since the statement can be quoted and referenced without fear of reprisal. In some cases, not all of the authors will agree to a retraction and this information should generally be included in a retraction notice. If the authors refuse to cooperate, a retraction notice may be issued by the editor, and/or publisher, or by the institution.

Expressions of concern may be used if the author's institution refuses to investigate the case, if the editor does not have confidence in the outcome of an investigation, or if an investigation is underway but will not report for some time. An expression of concern can alert readers to a potentially unreliable publiccation, but may later be converted into a retraction or correction, or itself retracted, depending on the outcome of the investigation. Authors (and institutions) sometimes request that an expression of concern be issued rather than a retraction, perhaps mistakenly viewing this as a less severe sanction and hoping to avoid a retraction. Journals therefore need clear policies on when retractions, corrections, and expressions of concern are appropriate. The COPE guidelines may be helpful in determining this [10].

Editors need to be aware that authors may request a retraction (or correction) on the grounds of an innocent error when, in fact, the case is subject to a misconduct inquiry. Using this tactic, the authors hope to have their work retracted without mention of any misconduct. To avoid this, if authors request a retraction but the editor has any suspicion that misconduct may have 
occurred, the authors' institution should be contacted to find out if an investigation is underway. It is usually advisable to wait until an investigation has concluded before issuing a retraction, so that the retraction notice can refer to its findings, but an expression of concern may be used to alert readers to an ongoing investigation.

\section{Journal responses to misconduct relating to unpublished submissions}

Journal responsibilities in cases that have been properly investigated by an appropriate authority are, in some respects, clearcut. Journals have a responsibility to protect readers from unreliable or misleading work and should therefore endeavour to publish a retraction or correction as soon as the investigation has concluded and found that published work is unreliable. However, cases relating to unpublished work raise special concerns for journals, especially if the institution is unresponsive. In such cases, editors may feel responsible for trying to prevent authors from submitting the work to another, less vigilant, journal, but they generally have no means to do this. Especially if no investigation has taken place, it is not usually appropriate to share information about suspectted misconduct with other editors. In response to this dilemma, COPE has issued a discussion document (but no formal guidance) on this topic [11]. One contributor to the discussion noted that such communications should be 'non-judgemental, factual and cautious'.

\section{Journal responses to institutions}

The COPE guidelines on cooperation between journals and institutions emphasize the importance of journals responding appropriately when contacted by an institution [1]. Such communication usually occurs at the conclusion of an investigation, to inform the journal of the outcome and of any affected publiccations. However, institutions may also contact journals to seek information. Sadly, journals do not always respond appropriately and, for example, sometimes fail to retract fraudulent or unethical work, despite clear communications from institutions or other investigatory bodies $[12,13]$.

\section{Journal responses to 'questionable practices' and minor offences}

Most editors would contact an institution only if they suspected the author had commit- ted a relatively serious form of misconduct such as major plagiarism or data fabrication. However, journals also need policies for handling so-called 'questionable practices' and minor offences which, while not considered full-blown misconduct, should, nonetheless be discouraged. For example, if a junior author copied a single sentence from another article in their Introduction, but this was detected before publication and the author advised to paraphrase it or put it in quotation marks, most editors would consider it disproportionate to inform their institution. On the other hand, if an entire article was plagiarised, editors would expect to inform the institution. Therefore journals need to determine how much copying constitutes plagiarism of sufficient severity to warrant informing the institution. The answer may not be straightforward, as plagiarism depends not only on the number of words copied, but also on their context and originality [14]. Similarly, defining redundant publication requires judgement, since there may be legitimate reasons for repeating parts of previous works, such as the methods section. However, while requiring editorial judgement and flexibility in their enforcement, journal policies are helpful to ensure consistency.

Editors also need to realise that their definitions of misconduct may differ from those of institutions. For example, submitting a manuscript to more than one journal simultaneously is outlawed by journals but may fall outside the definition of misconduct used by institutions and research integrity organizations. Similarly, including a senior figure who made little or no contribution to the work as a guest author would go against journal guidelines but may not be considered misconduct by an institution.

The COPE retraction guidelines state that the purpose of retractions is to correct the literature, not to punish authors. It can also be argued that journals have no legal standing to discipline authors, and that this should be left to their institution, employer or funder. Yet, editors sometimes seek to sanction authors, for instance by refusing to consider future submissions from them for a certain period. COPE does not endorse such sanctions, and such blacklisting could, in theory, make the journal (or publisher) vulnerable to legal action (such as suits for restriction of trade). However, other actions by journals may be more appropriate but may 
still have a deterrent effect. A letter from a journal editor expressing disappointment over the behaviour of an author or reviewer, but not requesting that the institution should investigate the case, may be effective, especially if copied to the individual's Head of Department or Dean. One editor (and former COPE Council member) described such correspondence as writing to authors 'more in sorrow than in anger'.

\section{The need to educate authors}

Problems sometimes arise because authors are unaware of the norms and conventions of scholarly publishing. Journal editors have an important opportunity to educate authors and peer reviewers (and, perhaps, also to reassure readers) both in their instructions and in occasional editorials. Journal submission systems should also be configured to make authors aware of journal policies and promote good practice (for example, by explaining authorship criteria and requiring disclosures of any conflicts of interest). It is impossible to make authors read such guidance, but providing it at least protects journals from author claims that they did not realise what they did was unacceptable. It is also helpful to provide information about how the journal handles cases of suspected misconduct and, in particular, the circumstances under which it would retract an article. The guidelines on Responsible Research Publication: International Standards for Authors developed at the $2^{\text {nd }}$ World Conference on Research Integrity in 2011 may be a useful resource for journals [6].

\section{Strengthening the link between journals and institutions}

Journals and institutions need to understand their different, but complementary, responsibilities in cases of possible research and publication misconduct. They also need to understand and respect the different constitutional and legal frameworks under which they operate. Editors have a responsibility for what they publish and a duty to rectify misleading publications. Editors also have important responsibilities because they are often the first people to have evidence of problems. However, journals should not attempt formal investigations - these should be the responsibility of the relevant institution. Such investigations and disciplinary proceedings are generally conducted confidentially and institutions in some countries may be constrained in the amount of information they can release (e.g. under employment law provisions). However, most institutions recognise the need for unreliable publications to be retracted and therefore for affected journals to be informed. Sadly, there are examples of institutions failing to respond to journals' requests for investigations and also instances of journals failing to respond appropriately to institutions $[4,12,13]$. As shown in this article, the correct response requires careful judgment. Following the correct procedures can also be time-consuming [15].

Further guidance on the difficult questions raised, and promoting understanding of the respective roles of journals and institutions, is needed. This topic was discussed at the $3^{\text {rd }}$ World Conference on Research Integrity in Montreal in 2013 [16]. It is hoped that these discussions will form the basis for further guidelines.

\section{Conclusion}

Journals and institutions have different constitutional and legal frameworks under which they operate, but complementary responsibilities and roles to play in cases of suspected research and publication misconduct. Editors should take responsibility for everything they publish and should alert institutions to initiate formal investigations into cases of possible serious misconduct. Institutions should respond to journals' requests for investigations of cases of possible misconduct and should inform journals if they have published unreliable or misleading articles. Such articles should be retracted or corrected. Following international standards, journals need to develop editorial and publishing policies, consistent with the policies of research institutions, to inform and educate researchers in research integrity, and for handling cases of suspected scientific and publication misconduct.

\section{Acknowledgments}

The author declares thatb there are no conflicts of interest.

\section{REFERENCES}

1. Wager E, Kleinert S. 2012. Cooperation between research institutions and journals on research integrity cases: guidance from the Committee on Publication Ethics (COPE). Maturitas 2012; 72: 165-9. 
2. COPE (Committee on Publication Ethics). Flowcharts. Available at: http://publicationethics.org/resources/flowcharts Accessed: Aug 20, 2014.

3. CSE (Council of Science Editors). Sample correspondence for an editorial office. Available at: http://www.councilscienceeditors.org/resource-library/editorial-policies/sample-correspondence-for-aneditorial-office/ Accessed: Aug 20, 2014.

4. Wager E. Coping with scientific misconduct. BMJ 2011; 343: d6586.

5. Elsevier. Publishing Ethics Resource Kit (PERK). Available at: http://www.elsevier.com/editors/perk Accessed: Aug 20, 2014.

6. Wager E, Kleinert S. Responsible Research Publication: International Standards for Authors. A position statement developed at the 2nd World Conference on Research Integrity, Singapore, July 22-24, 2010. Available at http://publicationethics.org/files/International\%20sta ndards_authors_for\%20website_11_Nov_2011.pdf Accessed: Aug 20, 2014.

7. Wiley-Blackwell. Best Practice Guidelines on Publication Ethics: A Publisher's perspective. Available at: http://authorservices. wiley.com/bauthor/publicationet hics.asp Accessed: Aug 20, 2014.

8. WAME (World Association of Medical Editors). The Principles of Transparency and Best Practice in Scholarly Publishing. Available at: www.wame.org Accessed: Aug 20, 2014.

9. COPE (Committee on Publication Ethics). Code of conduct. Available at:

http://publicationethics.org/resources/code-conduct Accessed: Aug 20, 2014.

10. COPE (Committee on Publication Ethics). Retraction guidelines. Available at:

http://publicationethics.org/files/retraction\%20guideli nes.pdf Accessed: Aug 20, 2014.

11. COPE (Committee on Publication Ethics). Sharing of information among editors-in-chief regarding possible misconduct. Available at:

http://publicationethics.org/files/u661/Forum_discussio n_summary_on_Sharing\%20of\%20information\%20am ong\%20editors_Final.pdf Accessed: Aug 20, 2014.

12. Elia N, Tramèr M, Wager E. Fate of articles that warranted retraction due to ethical concerns: a descriptive cross-sectional study. PLOS One 2014; 9:e85846.

13. Sox HC, Rennie D. Research misconduct, retraction, and cleansing the medical literature: Lessons from the Poehlman case. Ann Intern Med. 2006; 144: 609-13.

14. Wager E. Defining and responding to plagiarism. Learned Publishing. 2014; 27: 33-42.
15. Wager E, Williams P. Exploring why and how journal editors retract articles: findings from a qualitative study. Sci Eng Ethics. 2013; 19: 1-11.

16. Wager E, Kleinert S. Cooperation between Journals, Research Institutions and Funders over Research and Publication Integrity Cases: Defining the Challenges. Chapter in: Steneck NH, Anderson MS, Kleinert S, Mayer T, editors. Integrity in the Global Research Arena. World Scientific Press, Singapore. 2014/15. In press.

Р е $з$ и м е

\section{JA}

\section{?}

лиз бет гер

Публицистички консултант, „Сајдвју“, Велика Британија; визитинг-професор на Медицинскиот факултет, Универзитет во Сплит, Р. Хрватска

Списанијата и институциите имаат значајни комплементарни улоги во случаи на сомневање за истражувачко и публицистичко недолично однесување. Списанијата треба да преземат одговорност за сѐ што објавуваат и треба да ги алармираат институциите за случаи на можно сериозно недолично однесување, но не треба да се обидуваат да ги истражат ваквите случаи. Институциите треба да преземат одговорност за своите истражувачи и за испитување на случаите на можни злоупотреби и да ги информираат списанијата доколку тие објавиле неверодостојни или погрешни статии, така што тие може да се повлечат или поправат. Списанијата и институциите треба да имаат свои политики за постапување со вакви случаи и овие политики треба да ги почитуваат нивните различни улоги.

лучни зборови: публицистичка етика, недолично однесување во истражувањето, научни списанија, повлекување труд. 